\title{
Coronary Embolism
}

\section{ARSENIO CORDEIRO, CORTEZ PIMENTEL, FERNANDO LAGINHA, CARLOS RIBEIRO, AND HUMBERTO COSTA}

\author{
From the Department of Internal Medicine and Institute of Pathology, Lisbon University, Portugal
}

Embolism has been considered a rare cause of coronary occlusion and has been thought by some authors (Shrader, Bawell, and Moragues, 1956) to be almost invariably fatal. The first well-documented case diagnosed during life was reported by Mussafia (1948). Further cases were subsequently reported by Cordeiro and Dias Coelho (1951), Glushien, Reiter, and Fischer (1952), and Cheng, Cahill, and Foley (1953). In all but the last, the origin of emboli was bacterial endocarditis. In all except the case of Mussafia (1948), which survived at least a year, there was necropsy proof. Oakley, Yusuf, and Hollman (1961), in a paper discussing the significance of anginal pain in patients with mitral stenosis, reported one fatal and four nonfatal cases of coronary embolism and suggested that this was probably the commonest cause of ischæmic cardiac pain in mitral stenosis. In none of their five cases was bacterial endocarditis present.

The present authors have found that coronary embolism can be diagnosed in life with reasonable certainty if (a) undoubted myocardial infarction occurs; when (b) there exists a condition known to be associated with embolism, such as bacterial endocarditis, or other systemic embolism has clearly occurred, (c) the age and sex of the patient make coronary atheroma unlikely.

Five patients will be described in whom the diagnosis was made in life. Three of these patients died, and at necropsy myocardial infarction was found in the absence of coronary atheroma. In two of them the embolus itself was found. Three of these five came from a group of 120 patients with bacterial endocarditis followed in our department during the past 6 years.

\section{CAse Reports}

Case 1. E.G.D., a woman aged 25 years, was first Received June 16, 1965. admitted to hospital in 1959 with rheumatic mitral and aortic stenosis, atrial fibrillation, and heart failure. In 1960 she was readmitted five days after an episode of severe retrosternal pain of four hours' duration. Soon after admission she suffered a transient left hemiparesis. The electrocardiogram taken on admission showed atrial fibrillation, left ventricular hypertrophy, and anteroseptal infarction (Fig. 1). She made a complete recovery and has remained well ever since on digitalis and diuretic therapy.

Case 2. M.R.P., a woman aged 27 years, was first admitted in 1955 complaining of dyspnœea and palpitation and with signs of pure mitral stenosis and sinus rhythm. By 1959, atrial fibrillation had developed and she had paroxysmal dyspnœa. Anticoagulant therapy was started in preparation for mitral valvotomy. Two

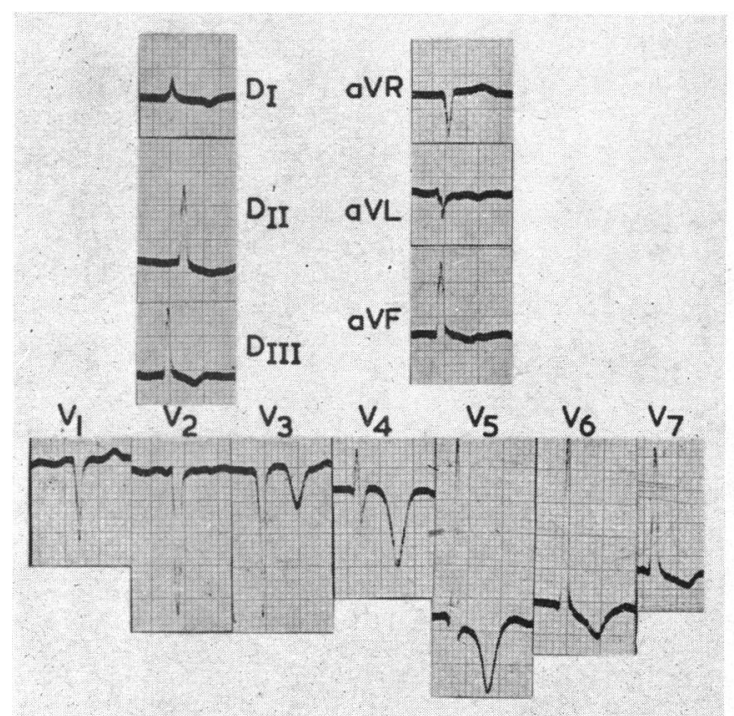

Fig. 1.-Case 1. Electrocardiogram recorded five days after præcordial pain. 
weeks later she developed anæmia, splenomegaly, a high sedimentation rate, and positive $\mathrm{C}$-reactive protein test. Blood cultures were negative, but a six-week course of penicillin and streptomycin was given. Splenomegaly and the abnormal blood findings disappeared. Valvotomy was postponed. One year later she had severe retrosternal pain which lasted for 10 hours; and a week after that she had an attack of diplopia and right hemiparesis. She was seen two months later, when she had mild heart failure. The electrocardiogram showed atrial fibrillation and old antero-septal myocardial infarction (Fig. 2).

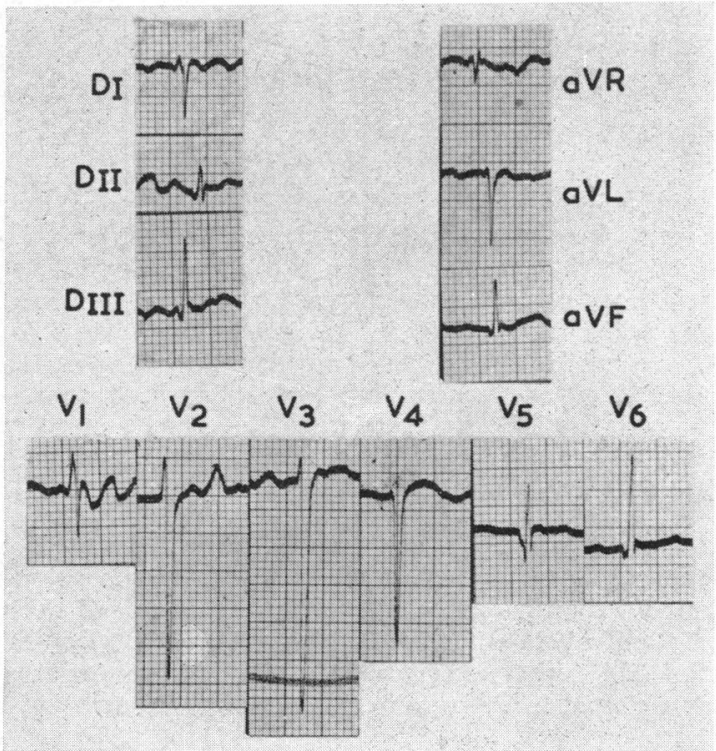

FIG. 2.-Case 2. Electrocardiogram recorded two months after the acute attack.

Case 3. I.R.T., a woman aged 40 years, had taken digitalis for 15 years when she was admitted to hospital in 1962 with heart failure. She had rheumatic heart disease with severe mitral regurgitation, functional tricuspid incompetence, and atrial fibrillation. Her condition continued to deteriorate and an electrocardiogram showed anterior myocardial infarction (Fig. 3). Deathoccurred 19 days after admission. Necropsy showed a severely incompetent mitral valve, a greatly dilated right ventricle, thrombosis in the left atrial appendage, and fresh septal infarction. There was no coronary atheroma.

Case 4. M.S.B.V., a woman aged 41 years, was admitted in 1962 with heart failure due to aortic stenosis and mitral regurgitation. There was hepatosplenomegaly; anæmia (Hb 63\%); WBC 7300, with 10 per cent eosinophils; and ESR (Westergren) 40-72 mm. Total serum protein was $6.8 \mathrm{~g} . / 100 \mathrm{ml}$., with 25.5 per cent $\gamma$-globulin. Creatinine clearance was $64 \mathrm{ml}$./min. Blood cultures were negative. Renal biopsy showed normal histology. The electrocardiogram revealed antero-septal infarction (Fig. 4).

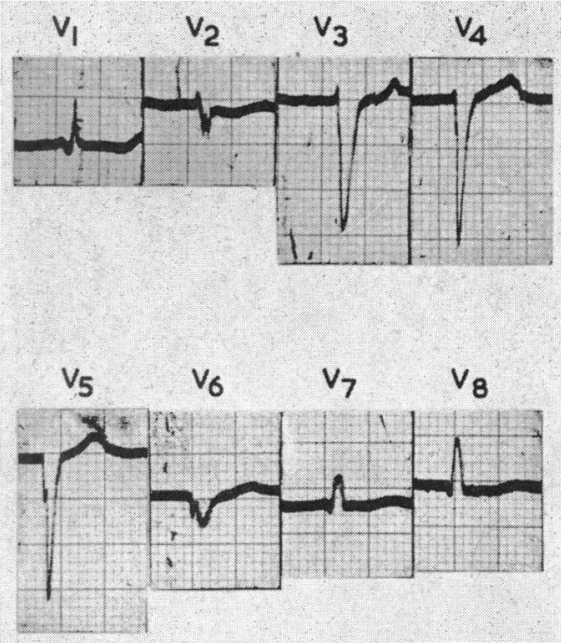

FIG. 3.-Case 3. Electrocardiogram recorded at the acute episode.

Subacute bacterial endocarditis with coronary embolism was diagnosed, and a two-month course of penicillin and streptomycin was given. Apart from another episode of failure later that year, she remained well thereafter until 1965, when she was readmitted with fever, rigors, back pain, and severe dyspnœe. She was cyanosed and slightly icteric and had evidence of pulmonary infarction in the right lower lobe. Pulmonary embolism was diagnosed, and anticoagulant therapy was started. Two days

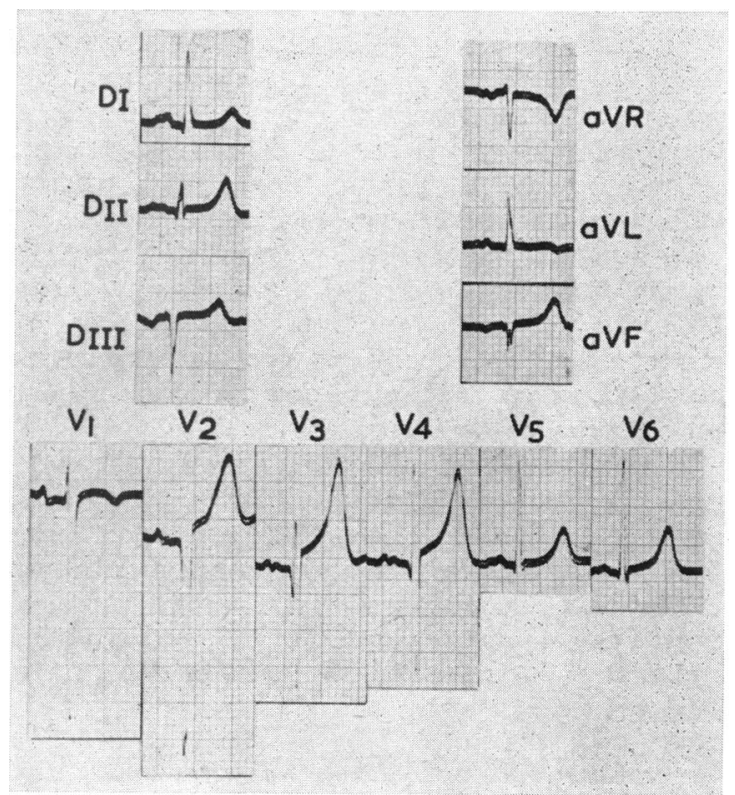

FIG. 4.-Case 4. Electrocardiogram showing old anteroseptal infarction. 


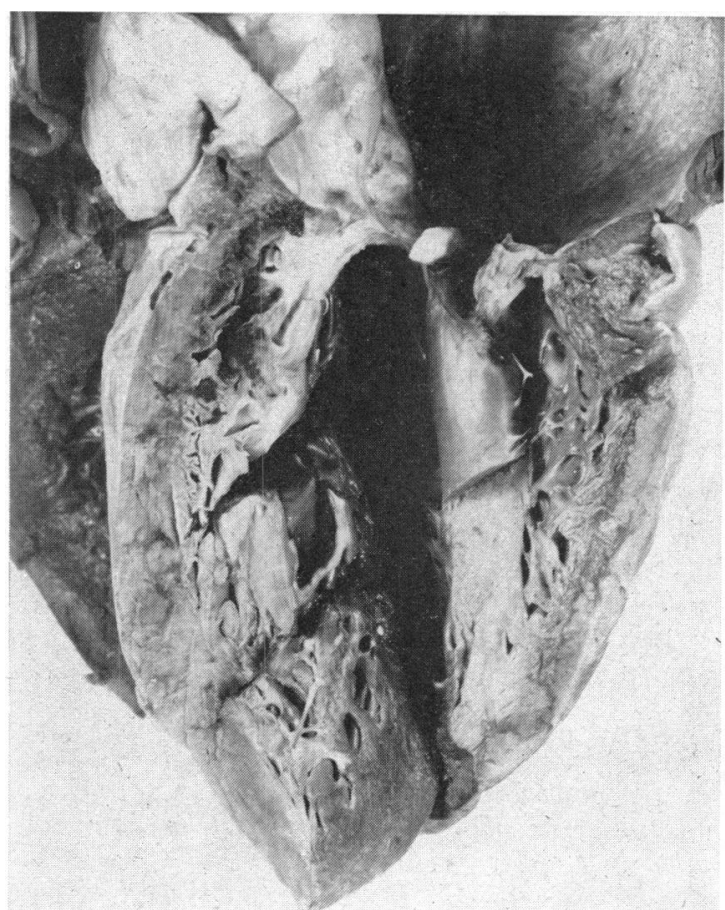

FIG. 5.-Case 4. Extensive scar of an old antero-septal infarct.

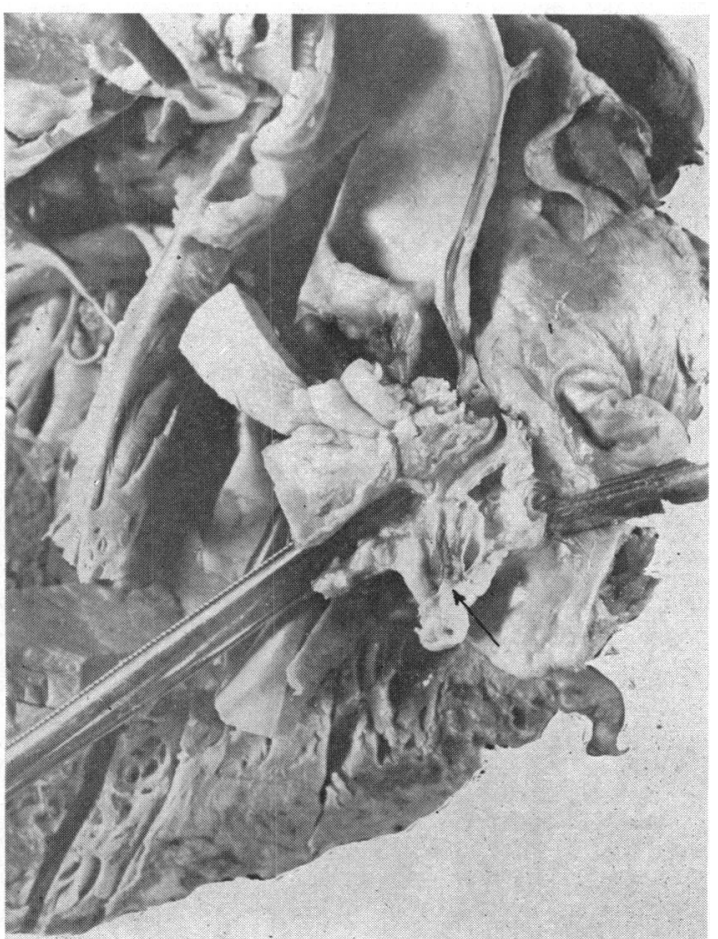

Fig. 6.-Case 4. Embolus in the lumen of the left coronary artery (arrow). later, however, she again developed severe dyspnœa, became shocked, and died. Necropsy showed rheumatic mitral, aortic, and tricuspid valve disease. The mitral valve was heavily calcified and showed healed polypoid vegetations. There was old and recent antero-septal infarction (Fig. 5). The coronary arteries were free from atheroma but an embolus was found in the anterior descending branch of the left artery (Fig. 6). There was also bilateral pulmonary infarction; and the kidneys showed chronic diffuse proliferative nephritis.

Case 5. M.A.M., a woman aged 32 years, was admitted with a history of dyspnœea and palpitation for 18 months; and orthopnœa, fever, anorexia, and weight loss for one month. She was pale and emaciated, with signs of aortic regurgitation. Hb 62 per cent, RBC 3.7 million, ESR $62-90 \mathrm{~mm}$., and C-reactive protein test positive. Subacute bacterial endocarditis was diagnosed, and penicillin and chloramphenicol were started. Two days later she developed severe anterior chest pain which lasted all day. The electrocardiogram showed recent postero-lateral myocardial infarction (Fig. 7). The SGOT was 238 units and SGPT 34 units. Progress was satisfactory, but 45 days later she experienced sudden dyspnœea and chest pain, developed irreversible shock, and died. Rheumatic mitral and aortic

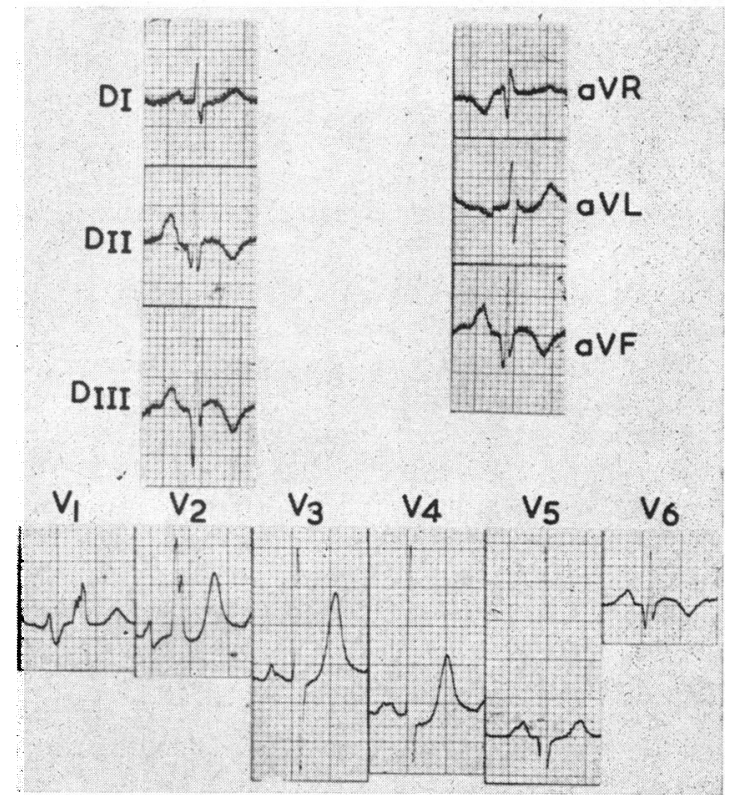

Fig. 7.-Case 5. Evolution of an acute postero-basal infarct.

valve disease, bacterial endocarditis, coronary embolism, and pulmonary embolism had been diagnosed. Necropsy showed tricuspid disease in addition, and there were healing vegetations of bacterial endocarditis on the aortic valve. The coronary arteries were free from atheroma but there was a large posterior myocardial infarct (Fig. 8) associated with an embolus in the right coronary artery (Fig. 9). 


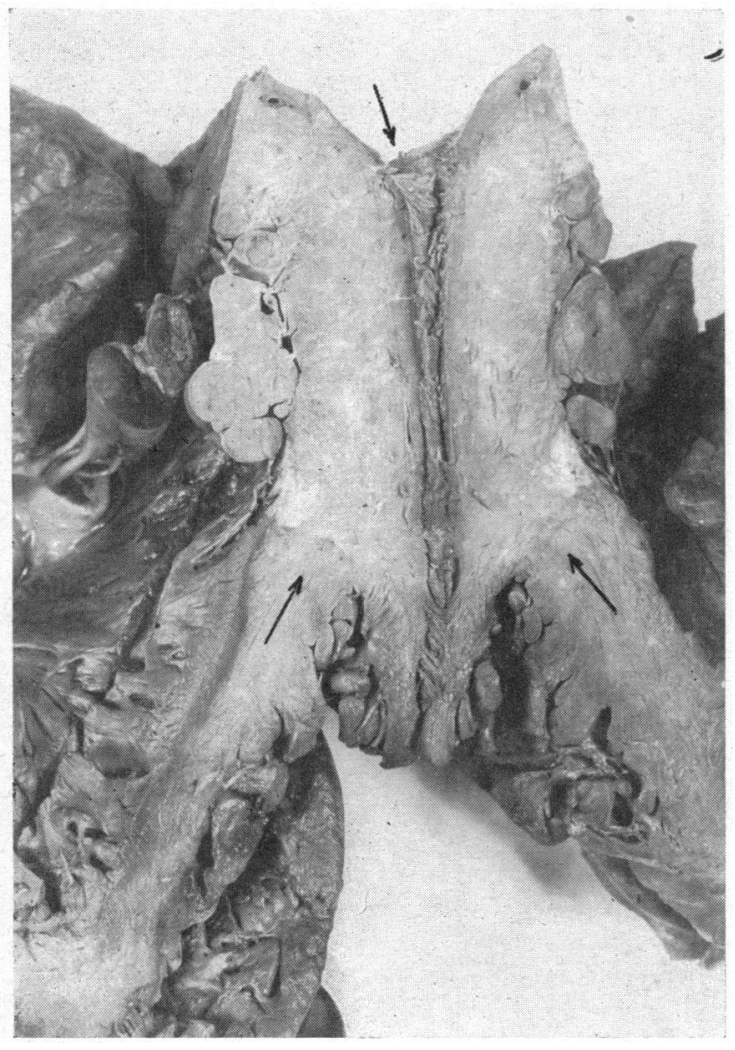

FIG. 8.-Case 5. Scar of old infarct in the posterior wall of the left ventricle.

\section{Discussion}

It is clear that bacterial endocarditis is a major cause of coronary embolism, and it is of interest that coronary embolism, a rare occurrence in itself, is a relatively common cause of death in subacute bacterial endocarditis. Saphir, Katz, and Gore (1950) reported 17 cases of coronary embolism among 75 fatal cases of bacterial endocarditis; and Cates and Christie (1951) found 13 per cent in their necropsy series.

Wenger and Bauer (1958), who reported 15 new cases and reviewed 64 previously published, pointed out the frequency of subacute bacterial endocarditis as the underlying cause of coronary embolism, and found that in 75 per cent of fatal cases the embolus was in the left coronary artery. In the present series, the embolus entered the anterior descending branch of the left coronary artery in all the cases except one.

Acute coronary occlusion may also occur from blockage of a coronary ostium by a large polypoid vegetation on the aortic valve. Cordeiro and Pimentel (1961) reported such a case, with occlusion of the right coronary ostium; and D. Paiva and

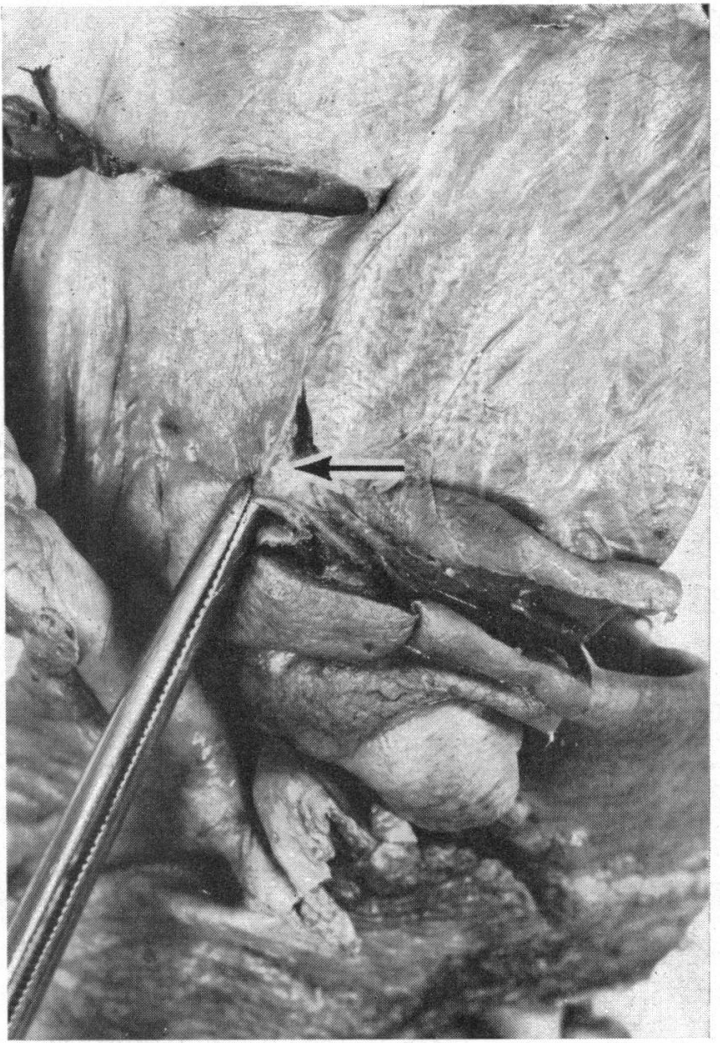

Fig. 9.-Case 5. Small embolus in the lumen of the right coronary artery (arrow).

C. Pimentel (unpublished observations) have described a further case. Both these patients died suddenly.

\section{SUMMARY}

Five cases of coronary embolism are described, two of which survived.

Features that point to the diagnosis of coronary embolism in life are enumerated.

It is shown that this condition is by no means so rare as has been thought, and that patients can survive myocardial infarction from this cause.

\section{REFERENCES}

Cates, J. E., and Christie, R. V. (1951). Subacute bacterial endocarditis-A review of 442 patients treated in 14 centres appointed by the Penicillin Trials Committee of the Medical Research Council. Quart. F. Med., 20, 93.

Cheng, J. T. O., Cahill, W. J., and Foley, E. F. (1953). Coronary embolism. F. Amer. med. Ass., 153, 211.

Cordeiro, A., and Dias Coelho, M. R. (1951). Um caso de embolia coronária. Gaz. méd. port., 4, 321.

- , and Pimentel, C. (1961). Novas fisionomias da endocardite bacteria-na sub-aguda. Rev. méd. Angola, 13, 5. 
Glushien, A. S., Reiter, M. D., and Fischer, H. (1952). Coronary embolism (intra vitam diagnosis) and necrotizing renal papillitis. Ann. intern. Med., 36, 679.

Mussafia, A. (1948). Embolia coronarica in corso di endocardite batterica subacuta. Cuore e Circol., 32, 91.

Oakley, C., Yusuf, R., and Hollman, A. (1961). Coronary embolism and angina in mitral stenosis. Brit. Heart f., 23, 357.
Saphir, O., Katz, L. N., and Gore, I. (1950). The myocardium in subacute bacterial endocarditis. Circulation, $1,1155$.

Shrader, E. L., Bawell, M. B., and Moragues, V. (1956). Coronary embolism. Circulation, 14, 1159.

Wenger, N. K., and Bauer, S. (1958). Coronary embolism. Review of the literature and presentation of fifteen cases. Amer. F. Med., 25, 549. 